\title{
ANALISIS PENGARUH UTANG BERBASIS BUNGA DAN PENDAPATAN NON-HALAL TERHADAP NILAI PERUSAHAAN EMITEN SAHAM SYARIAH
}

\author{
Muhammad Adlan \\ Program Studi S1 Ekonomi Islam, Universitas Airlangga \\ Email: muhammad.adlan-2014@feb.unair.ac.id \\ Imron Mawardi \\ Departemen Ekonomi Syariah, Universitas Airlangga \\ Email: ronmawardi@gmail.com
}

\section{ARTICLE HISTORY}

Received:

11 Oktober 2018

Accepted:

20 Desember 2018

Online available:

30 Desember 2018

\section{Keywords:}

Interest baseddebt, Non-halal income, Sharia stocks, Value of the firm

\section{ABSTRACT}

This study aims to determine whether interest-based debt limitation and non-halal income limitation have significant effect on the firm value. Sharia stock issuers in Indonesia are obliged to pass several conditions set by the market regulator, some of them are limitations of the interest-based debt and non-halal income. This study assumes that the lower portion of interestbased debt and non-halal income, the more the investors will prefer the stocks, thus increasing the firm value. The subjects of this study are the companies listed on JII period 2013-2017. This study measures interest-based debt with ratio of interest-based debt devided by total debt, measures non-halal income with ratio of non-halal income divided by operating revenue, and measures the value of the firm with PBV. The analysis of this study using panel data regressions with fixed effects models with robust standard errors. The results shows that interestbased debt and non-halal income have no effects on the value of the firm, partially and simultaneously

\section{ABSTRAK}

Kata Kunci: Hutang berbasis bunga, pendapatan nonhalal, Saham Syari'ah, Nilai Perusahaan
Tujuan dari penelitian ini adalah untuk mengetahui apakah pembatasan hutang berbasis bunga dan pembatasan pendapatan nonhalal memiliki pengaruh yang signifikan terhadap nilai perusahaan. Penerbit saham syari'ah di Indonesia diwajibkan untuk memenuhi beberapa syarat yang diatur oleh regulator pasar, syarat-syarat tersebut di antaranya adalah pembatasan hutang berbasis bunga dan pendapatan nonhalal. Penelitian ini memprediksi bahwa semakin rendah angka hutang berbasis bunga dan pendapatan nonhalal, maka semakin banyak investor yang memburu sahamnya sehingga meningkatkan nilai saham perusahaan yang bersangkutan. Perusahaan yang diteliti adalah perusahaan yang terletak pada papan JII periode 20132018. Penelitian ini mengukur hutang berbasis bunga dengan rasio hutang berbasis buga dibagi dengan total hutang, 
mengukur pendapatan nonhalal dengan rasio pendapatan nonhalal dibagi dengan jumlah pendapatan operasional, dan mengukur nilai perusahaan dengan rasio PBV. Analisis ini menggunakan data panel melalui metode regresi dengan model fix effect dan robust standard errors. Hasil penelitin ini menunjukkan bahwa hutang berbasis bunga dan pendapatan nonhalal tidak memiliki pengaruh terhadap nilai perusahaan secara parsial maupun simultan.

\section{PENDAHULUAN}

Melakukan investasi berarti menukarkan aset dalam bentuk kas kedalam bentuk aset lain dengan harapan berupa manfaat arus kas masuk di masa yang akan datang atau kenaikan nilai dari aset investasi (Fabozzi dan Modigliani, 2003:2). Hal utama yang harus dicermati oleh investor dalam berinvestasi adalah kebijakankebijakan perusahaan yang menjadi dasar kinerja perusahaan. Pada dasarnya, kebijakan-kebijakan yang diambil oleh perusahaan adalah bertujuan untuk memaksimalkan nilai atau memberi hasil investasi bagi investor (Ross, et.al., 2015:9). Bagi investor, informasi mengenai kebijakan dan kinerja perusahaan dapat diketahui melalui laporan keuangan dan menjadikannya sebagai bahan pertimbangan, termasuk keputusan membeli, mempertahankan atau menjual investasi pada perusahaan tersebut (Harahap, 2012:125). Investor akan cenderung memilih perusahaan dengan kinerja terbaik menurut mereka. Semakin baik kinerja yang dihasilkan perusahaan, maka investor akan semakin percaya pada perusahaan tersebut. Tingkat kepercayaan investor kepada perusahaan ini yang kemudian disebut sebagai nilai perusahaan (Verawaty, et.al., 2016:16).

Bagi seorang investor muslim, melakukan kegiatan pengelolaan investasi tidak boleh hanya berpedoman pada kinerja keuangan perusahaan, melainkan juga harus memperhatikan pada aspek kesyariahan perusahaan. Adapun aturan penerbitan saham syariah di Indonesia yang diatur dalam peraturan Bapepam dan LK nomor II.K.1 mengharuskan emiten yang terdaftar dalam Daftar Efek Syariah untuk membatasi jumlah instrumen keuangan berbasis bunga. Dalam peraturan tersebut dinyatakan bahwa emiten syariah tidak boleh memiliki rasio total utang berbasis bunga dibandingkan dengan total aset hingga melebihi $45 \%$ serta tidak boleh memiliki rasio total pendapatan bunga dan pendapatan tidak halal lainnya dibandingkan dengan total pendapatan usaha (revenue) ditambah pendapatan lainlain hingga melebihi $10 \%$.

Dalam Q.S. al-Baqarah: 278, Allah berfirman: "Wahai orang-orang yang beriman! Bertakwalah kepada Allah dan tinggalkan sisa riba (yang belum dipungut) jika kamu orang beriman." (Al-Baqarah (2): 278, dalam Al-Quran Kementerian Agama 
Republik Indonesia Online). Pendapat beberapa ulama, seperti Abu Zahra, Abu A'la al-Maududi, M. Abdallah al-Araby, Yusuf Qardhawi, dan Sayyid Sabiq, sebagaimana dikutip dalam Ghazaly, dkk. (2012:223) menyatakan bunga bank adalah sama dengan riba, dan karena itu hukum bunga adalah haram dalam Islam. Berdasarkan hukum bunga bank tersebut, maka termasuk di dalam aspek kesyariahan bagi perusahaan adalah dengan meminimalkan rasio-rasio keuangan berbasis bunga sebagaimana yang disyaratkan dalam Peraturan Bapepam dan LK. Semakin baik kinerja perusahaan dalam mengelola instrumen keuangan berbasis bunga seminimal-minimalnya, maka seharusnya saham perusahaan tersebut semakin disukai oleh investor muslim. Dengan demikian nilai perusahaan akan meningkat.

Tabel 1.1 menunjukkan data yang diambil secara acak dari beberapa perusahaan terbuka yang tercatat pada papan utama bursa dan terdaftar dalam Indeks Saham Syariah Indonesia pada tahun 2013 - 2016. Data tersebut terdiri dari beban bunga dan pendapatan non-halal untuk menggambarkan transaksi berbasis bunga yang dilakukan oleh perusahaan, serta harga saham untuk sekilas menggambarkan nilai perusahaan. Ketiga unsur tersebut kemudian dihitung rata-rata dan dibandingkan satu sama lain.

Sedangkan gambar 1.1 menunjukkan grafik perbandingan antara rata-rata beban bunga, pendapatan non-halal dan harga saham tiap tahun. Gambar 1.1 menunjukkan kenaikan beban bunga dan pendapatan non-halal setiap tahun. Namun kenaikan beban bunga dan pendapatan non-halal justru terlihat menghambat kenaikan harga saham, bahkan terjadi penurunan pada tahun 2015. Perbandingan tersebut menunjukkan kemungkinan adanya hubungan terbalik antara transaksi keuangan berbasis riba terhadap harga saham emiten syariah.

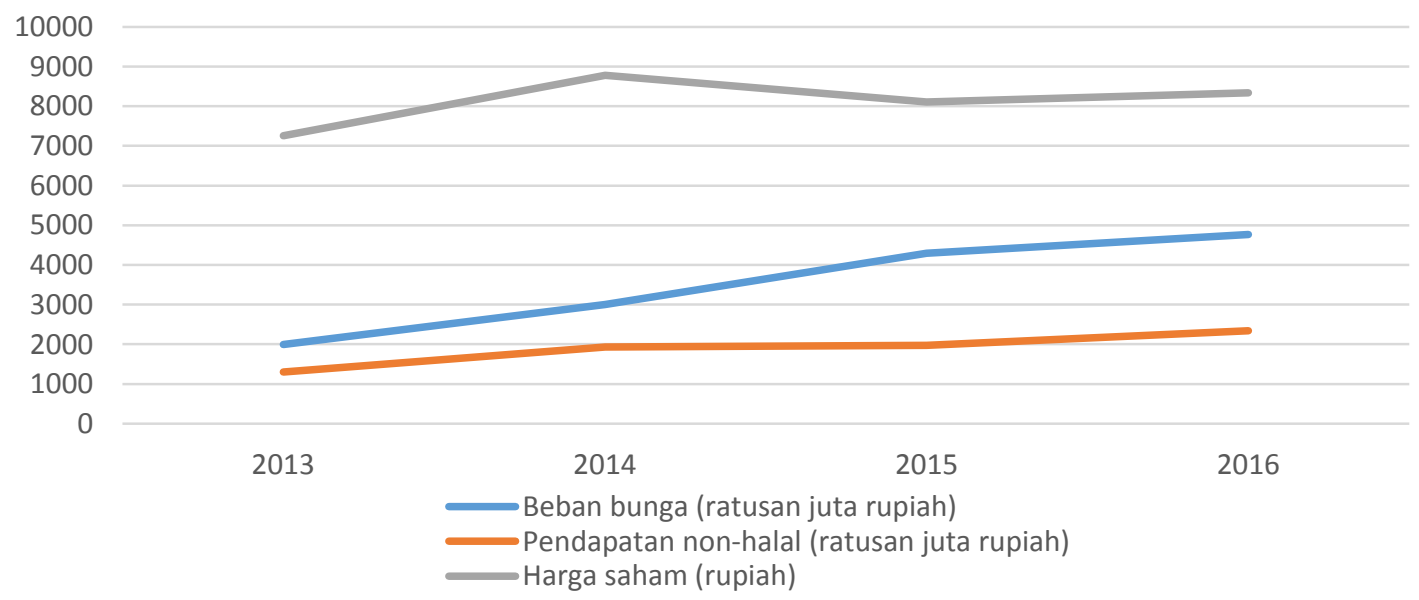

Sumber: Indopremier.com; Laporan Keuangan masing-masing perusahaan, diolah

Gambar 1. Grafik Perbandingan Rata-rata Beban Bunga, Pendapatan Non-Halal, dan Harga Saham 
Tabel 1

Perbandingan Beban Bunga, Pendapatan Non-halal dan Harga Saham

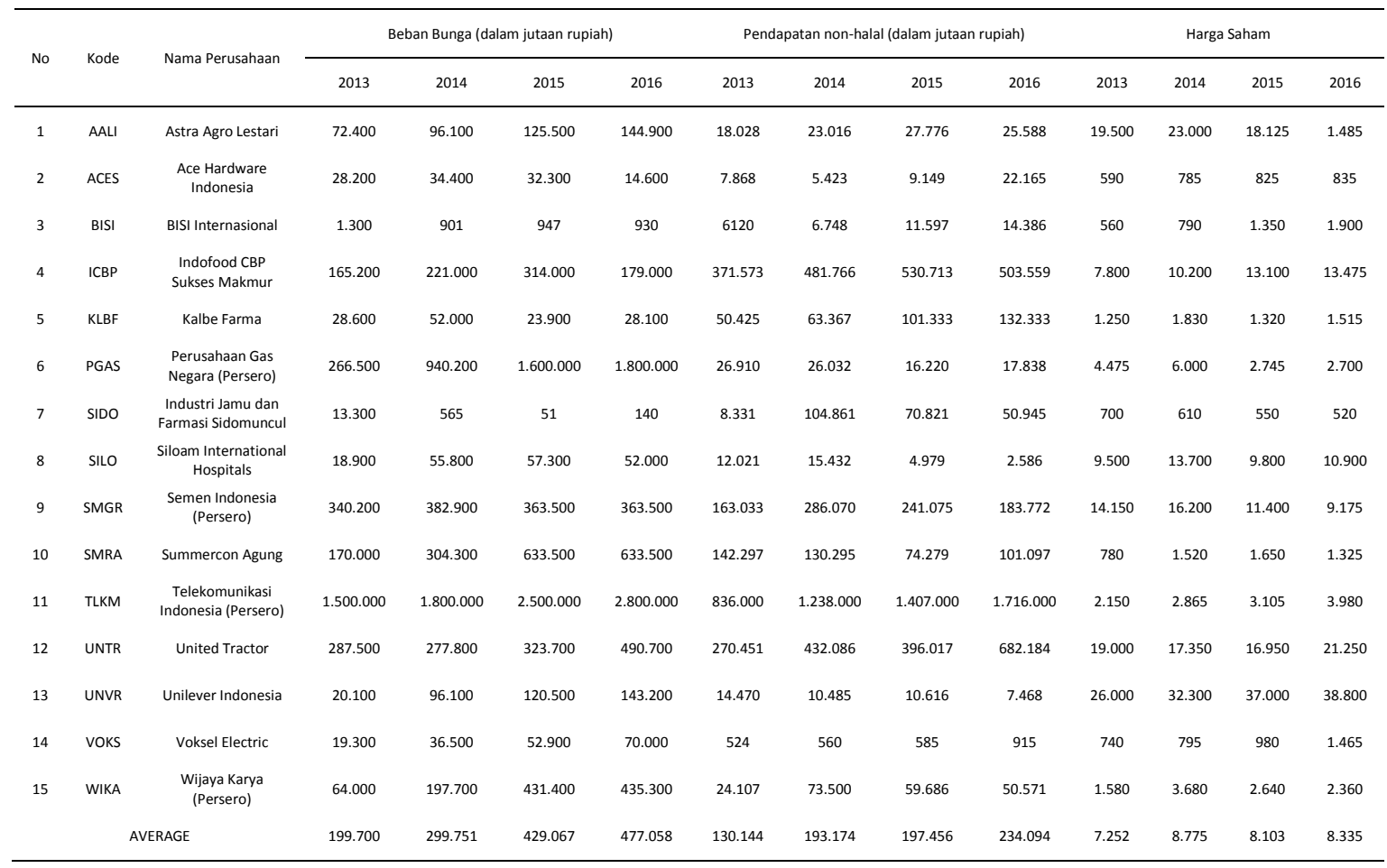

Sumber: Indopremier.com; Laporan Keuangan masing-msing perusahaan, diolah

Penelitian ini bermaksud untuk mengukur lebih jauh tentang pengaruh kepatuhan syariah terhadap saham perusahaan. Pengukuran kepatuhan syariah melalui dua rasio keuangan sebagai syarat sebuah emiten syariah akan diuji pengaruhnya terhadap nilai perusahaan. Pada akhirnya, penelitian ini mencari tahu apakah keputusan perusahaan untuk membatasi instrumen keuangan berbasis bunga dapat menjadi salah satu bahan pertimbangan investor untuk melakukan investasi.

\section{LANDASAN TEORI}

Ilmu ekonomi mempelajari perilaku manusia sebagai pelaku kegiatan ekonomi yang sering disebut sebagai homo economicus (manusia ekonomi). Dalam kajian ilmu ekonomi tersebut, homo economicus memiliki atribut dasar yakni rasionalitas (Vriend, 1996:264). Rasionalitas dapat diartikan sebagai tindakan memaksimalkan manfaat pada tingkat biaya tertentu, atau meminimalkan biaya pada tingkat manfaat tertentu (McEachern, 2006:6). Konsep rasionalitas ini sangat erat kaitannya dengan konsep self-interest dalam ilmu ekonomi. Edgeworth menyatakan bahwa prinsip pertama dalam ilmu ekonomi adalah bahwa setiap perilaku ekonomi seorang individu semata digerakkan oleh kepentingan pribadi (self-interest) individu tersebut (Vriend, 1996:265; Al Arif \& Amalia, 2010:68). 
Asumsi rasionalitas juga dapat diberlakukan pada perilaku investor dalam berinvestasi. Teori portofolio efisien yang pertama kali dikembangkan oleh Harry Markowitz menyatakan bahwa seorang investor, yang diasumsikan sebagai seorang penghindar risiko (risk averse), akan berusaha untuk memaksimalkan tingkat expected return pada tingkat risiko tertentu. Pernyataan alternatif dari teori ini adalah bahwa investor akan berusaha meminimalkan risiko yang diterima pada tingkat expected return tertentu (Fabozzi \& Modigliani, 2003:126). Pernyataan tersebut berimplikasi pada tujuan investasi, yakni untuk memaksimalkan kepuasan investor itu sendiri (Mayo, 2017:156).

Lebih lanjut, demi mencapai tujuan memaksimalkan tingkat pengembalian dan meminimalkan risiko, seorang investor biasanya akan melakukan rangkaian proses analisis sebelum mengambil keputusan investasi. Proses analisis sekuritas, terutama pada saham, biasanya melibatkan paling tidak tiga tahap analisis, yaitu: analisis kondisi ekonomi, kondisi sektor/industri, dan analisis perusahaan (Jones, et.al, 2009).

Konsep homo economicus dalam ilmu ekonomi konvensional, oleh para ekonom muslim, dinilai tidak cukup untuk menjelaskan dimensi manusia yang lebih luas karena hanya menyandarkan perilaku manusia pada hasrat material. Para ekonom muslim kemudian mengajukan konsep homo Islamicus (manusia Islami) yang mengacu pada perilaku individu yang dituntun oleh syariat Islam (Hoetoro, 2017). Sebagaimana konsep homo economicus, homo Islamicus juga diperkenalkan dengan membawa atribut dasarnya berupa rasionalitas. Rasionalitas homo Islamicus merupakan konsep yang lebih luas yang mencakup aspek hasrat diri (self-interest), hubungan sosial, dan pengabdian kepada Allah. Rasionalitas ekonomi Islam tidak hanya didasarkan pada pemuasan diri yang bersifat material duniawi saja, melainkan berorientasi dunia dan akhirat, yakni mencapai falah (Hoetoro, 2017).

Bagi seorang investor muslim, sesuai dengan rasionalitas homo islamicus, tujuan investasi seharusnya tidak hanya terbatas pada memaksimalkan tingkat pengembalian dan meminimalkan risiko secara materi, namun bertujuan sebagai bentuk ibadah kepada Allah. Agustin \& Mawardi (2014) mengidentifikasi bahwa investor muslim yang mempertimbangkan faktor agama dalam berinvestasi, disamping faktor rasionalitas lainnya, hanya akan berinvestasi pada saham-saham yang terindeks dalam indeks saham syariah. Hal ini tak lepas dari segi ibadah dalam berinvestasi yang diyakini oleh investor muslim tersebut. Menurut Umar (2017), keimanan dapat menjadi salah satu dasar keputusan untuk berinvestasi pada sekuritas yang sesuai dengan syariah. Tahir dan Brimble (2011) lebih rinci menyatakan bahwa tingkat religiositas investor dapat memengaruhi keputusan investasinya. Semakin tinggi tingkat religiositas seorang investor, keputusan investasi yang dibuat akan semakin ketat terhadap aturan syariah. Semakin tinggi tingkat religiositas seorang investor, maka semakin sedikit alokasi dananya pada sahamsaham yang tidak memenuhi kriteria syariah, hingga pada akhirnya, tidak ada alokasi dana pada saham non-syariah. 
Dalam al-Quran surat al-Jum'uah (62): 10, Allah berfirman: "Apabila salat telah dilaksanakan, maka bertebaranlah kamu di bumi; carilah karunia Allah dan ingatlah Allah banyak-banyak agar kamu beruntung." (Q.S. Al-Jumu'ah (62): 10, Al-Quran Kementerian Agama Republik Indonesia Online). Ayat ke-10 dari al-Quran surat alJumuah tersebut merupakan dasar diperbolehkannya seseorang untuk berniaga, menunaikan keperluan-keperluan penghidupan, dan mencari rezeki berupa keuntungan dari bertransaksi dan kegiatan ekonomi (Az-Zuhaili, 2014:571). Kebolehan yang ditunjukkan pada ayat tersebut mencakup kegiatan apapun yang tidak melanggar larangan Allah (Shihab, 2002:59). Berdasarkan ayat tersebut, fatwa DSN-MUI nomor: 40/DSN-MUI/X/2003 dan Peraturan Bapepam dan LK nomor IX.A.13 menyebutkan bentuk-bentuk kegiatan bisnis yang dilarang oleh syariat bagi emiten syariah, yang juga disebut core business screening (Yafiz, 2008), yaitu: perjudian, lembaga keuangan konvensional, perdagangan yang dilarang syariat, jual beli risiko, penyedia barang/jasa yang haram dan merusak moral atau bersifat mudarat, serta usaha yang mengandung unsur suap.

Selain kriteria jenis usaha, perusahaan yang dapat menerbitkan efek syariah harus memenuhi kriteria rasio-rasio keuangan tertentu, yang dapat juga disebut sebagai financial ratio screening (Yafiz, 2008). Kriteria rasio-rasio keuangan yang dimaksud tertuang dalam Peraturan Bapepam dan LK nomor II.K.1 yang telah disebutkan sebelumnya. Peraturan tentang kriteria rasio keuangan tersebut menjadi pembatas untuk perusahaan dalam melakukan transaksi-transaksi keuangan berbasis bunga. Peraturan Bapepam dan LK nomor IX.A.13 dan nomor II.K.1 merupakan landasan legal investasi syariah di Indonesia.

International Shari'ah Research Academy for Islamic Finance/ISRA (2011:483) menyatakan jika pasar modal syariah menerapkan aturan ketat yang mengharuskan emiten untuk tidak melakukan transaksi berbasis bunga sama sekali, maka untuk saat ini akan sangat membatasi jenis saham yang dapat dijadikan sarana investasi bagi investor muslim. Rahman, et.al. (2010:231) menjelaskan bahwa pendapat mayoritas menyatakan kebolehan transaksi keuangan berbasis bunga dengan batasan-batasan tertentu.

Dalam hal ini, berlaku kaidah fikih yang berbunyi: "Apa yang tidak bisa dilaksanakan seluruhnya, jangan ditinggalkan seluruhnya." Kaidah tersebut menunjukkan bahwa jika suatu perintah tidak bisa dilakukan secara penuh, tidak berarti perintah tersebut menjadi tidak berlaku, melainkan harus dilakukan semampunya (Djazuli 2017:98). Dalam hal transaksi berbasis bunga yang dilakukan oleh emiten syariah, jika tidak bisa menghindari riba secara menyeluruh, maka perlu diusahakan untuk menghindari sebagian porsinya sesuai kemampuan.

Secara umum, tujuan manajemen keuangan perusahaan adalah untuk memaksimalkan kekayaan pemilik perusahaan dengan cara memaksimalkan harga saham yang nantinya akan meningkatkan nilai perusahaan (Berk, et.al., 2013:40). Nilai perusahaan, yang dicerminkan oleh harga saham, bergantung pada kekuatan 
permintaan dan penawaran di pasar (Keown, dkk., 2001 dalam Maryanti \& Tjahjadi, 2013:50). Semakin baik persepsi investor terhadap perusahaan, maka semakin tinggi pula penawaran sahamnya di pasar dengan harga yang tinggi. Semakin tinggi harga saham, semakin tinggi pula nilai perusahaan (Verawaty, et.al, 2016:16).

Nilai perusahaan umumnya dipengaruhi oleh kinerja keuangan perusahaan, terutama kemampuan perusahaan dalam menghasilkan keuntungan (Sudana, 2011:148). Sabrin, et.al. (2016) meneliti bahwa kemampuan perusahaan terbuka sektor manufaktur di Indonesia dalam menghasilkan keuntungan berpengaruh positif terhadap nilai perusahaannya. Hasil serupa juga ditemukan pada penelitian Rochmah \& Fitria (2017) yang meneliti profitabilitas perusahaan terbuka sektor real estate pada BEI dan pengaruhnya terhadap nilai perusahaan.

Selain profitabilitas perusahaan, struktur modal juga dapat memengaruhi nilai perusahaan. Cheng \& Tzeng (2011) meneliti bahwa tingkat utang berpengaruh positif terhadap nilai perusahaan yang terdaftar di bursa efek Taiwan pada tahun 2000-2009 sebelum tingkat utang mencapai tingkat optimalnya. Sementara penelitian Paminto, dkk (2016) yang meneliti pengaruh struktur modal terhadap nilai perusahaan perkebunan sawit yang terdaftar dalam BEI pada tahun 2007-2011 menunjukkan hasil bahwa struktur modal justru berpengaruh negatif signifikan terhadap nilai perusahaan.

Dalam hubungan antara manajer perusahaan dan pemilik perusahaan, manajer perusahaan hampir selalu memiliki informasi yang lebih baik mengenai kondisi perusahaan, (Lo, 2012:2). Berlandaskan pada asumsi bahwa keputusan manajer keuangan untuk memaksimalkan nilai perusahaan, manajer keuangan akan melakukan usaha tertentu untuk memberi sinyal tentang kondisi perusahaan kepada investor sehingga kondisi ketimpangan informasi dapat diatasi. Sinyal positif akan direspon dengan persepsi baik investor, sedangkan sinyal negatif akan direspon dengan persepsi buruk investor. Persepsi baik akan meningkatkan nilai perusahaan, sedangkan persepsi buruk akan berimbas pada penurunan nilai perusahaan (Gitman, 2006:562).

Teori sinyal biasanya terkait dengan aksi keuangan perusahaan yang mencerminkan persepsi manajer terhadap prospek perusahaan. Misalkan, ketika perusahaan menambah jumlah utang, manajemen berekspektasi bahwa perusahaan memiliki prospek yang baik di masa yang akan datang, termasuk kemampuan melunasi utang. Hal inilah yang akan dibaca sebagai sinyal positif oleh investor sehingga nilai perusahaan akan naik (Sudana, 2011:153). Hasil penelitian Cheng \& Tzeng (2011) yang telah disebutkan sebelumnya dapat dijelaskan dengan teori sinyal karena investor melihat penambahan utang merupakan sinyal positif akan prospek perusahaan di masa yang akan datang. Selain keputusan utang, keputusan investasi juga dapat diartikan sebagai sinyal positif oleh investor karena dianggap sebagai prospek pertumbuhan perusahaan di masa yang akan datang. Penelitian Verawaty, 
dkk. (2016) menunjukkan hasil pengaruh positif dari kebijakan investasi terhadap nilai perusahaan manufaktur yang terdaftar dalam BEI tahun 2013.

Disamping keputusan utang dan investasi, beberapa keputusan perusahaan yang tidak berhubungan langsung dengan prospek kinerja keuangan di masa yang akan datang juga dapat berlaku sebagai sinyal. Lys et.al. (2015) misalnya, meneliti hubungan positif kegiatan CSR dengan kinerja keuangan dan nilai perusahaan yang disebut sebagai "doing well by doing good". Penelitian tersebut menjelaskan bahwa keputusan perusahaan untuk melakukan kegiatan CSR adalah bentuk persepsi manajer akan prospek baik perusahaan di masa yang akan datang. Oleh karena itu, manajer dapat mengirimkan sinyal tersebut kepada investor dengan mengungkapkan kegiatan CSR dalam laporan keuangan atau laporan tahunan.

Keputusan perusahaan terkait aspek syariah perusahaan juga dapat menjadi sinyal bagi investor religius yang memperhatikan aspek kesyariahan dalam berinvestasi. Hal ini sesuai dengan prinsip rasionalitas dan keputusan investasi bagi seorang muslim (Berg \& Kim, 2014). Alahqatani \& Boulanouar (2017) menemukan bahwa perusahaan yang memenuhi kepatuhan syariah yang melakukan IPO pada bursa efek Arab Saudi pada tahun 2004-2011 lebih disukai oleh investor daripada perusahaan non-syariah. Sedangkan pada kasus bursa efek Malaysia, Yazi et.al. (2015) meneliti perubahan aturan screening pada Shariah-compliant Stock (SCS) pada tanggal 29 November 2013 yang menyebabkan 158 perusahaan keluar dari daftar SCS. Hasil penelitian tersebut menunjukkan bahwa perusahaan yang tetap berada dalam daftar SCS mengalami kenaikan harga saham, sedangkan perusahaan yang keluar dari daftar SCS mengalami penurunan harga saham.

\section{PENGEMBANGAN HIPOTESIS}

Dari penjabaran teori dan penelitian terdahulu, dapat diketahui bahwa nilai perusahaan dapat dipengaruhi oleh preferensi investor. Preferensi tersebut dapat berupa preferensi terhadap aspek yang menggabungkan aspek risiko dan tingkat pengembalian sebagaimana yang dijelaskan dalam teori portofolio Markowitz dalam Fabozi \& Modigliani (2003:126). Preferensi tersebut juga dapat dipengaruhi karena keputusan keaungan perusahaan, seperti penambahan utang (Sudana, 2011; Cheng \& Tzeng, 2011), atau keputusan investasi perusahaan (Verawaty, dkk., 2016). Selain itu, tindakan perusahaan dalam melakukan kebaikan, secara tidak langsung juga dapat memengaruhi preferensi investor (Lys et.al., 2015).

Melalui mekanisme yang dijelaskan dalam teori sinyal, manajemen dapat memberikan sinyal positif untuk mengurangi ketimpangan informasi antara manajemen dan investor agar investor tertarik pada saham perusahaan tersebut (Gitman, 2006:562). Semakin baik respon investor pada sinyal yang diberikan oleh perusahaan, maka semakin tinggi nilai perusahaan tersebut.

Kepatuhan syariah yang dilakukan oleh perusahaan dapat sangat berpengaruh pada preferensi investor yang mempertimbangkan aspek kesyariahan dalam 
berinvestasi. Investor religius akan cenderung memilih saham yang patuh syariah daripada saham non-syariah (Tahir \& Brimble, 2011; Berg \& Kim, 2014; Agustin \& Mawardi, 2014; dan Umar, 2017). Preferensi investor dalam memilih saham-saham yang patuh syariah akan meningkatkan permintaan terhadap saham tersebut dan akan meningkatkan nilai perusahaannya (Alahqatani \& Boulanouar, 2017; Yazi et.al., 2015).

Peraturan tentang pembatasan transaksi berbasis bunga pada financial ratio screening merupakan titik batas bagi emiten untuk dinyatakan sesuai syariah. Jika merujuk pada aturan syariah dalam al-Quran dan hadits, transaksi berbasis riba harusnya tidak ada sama sekali. Namun jika merujuk pada kaidah fikih "Apa yang tidak bisa dilaksanakan seluruhnya, jangan ditinggalkan seluruhnya," pembatasan jumlah transaksi berbasis riba tersebut dapat dilakukan. Namun juga harus dapat dipahami bahwa kaidah tersebut menuntut adanya pelaksanaan syariat semaksimalmaksimalnya sesuai kemampuan.

Jika dihubungkan dengan peraturan pembatasan transaksi berbasis riba pada emiten syariah, semakin sedikit tingkat utang berbasis bunga dan tingkat pendapatan non-halal yang dimiliki perusahaan, dapat dikatakan bahwa perusahaan semakin baik dalam menerapkan aspek kesyariahan dalam kegiatannya. Meminjam istilah "doing well by doing good" dalam Lys et.al. (2015), pelaksanaan aspek kesyariahan yang semakin baik oleh perusahaan akan dapat menjadi sinyal positif bagi investor yang memperhatikan aspek kesyariahan dalam berinvestasi dan akan meningkatkan nilai perusahaan yang menerapkannya. Artinya ada hubungan negatif antara jumlah transaksi berbasis bunga dengan nilai perusahaan emiten syariah.

Berdasarkan kerangka berpikir yang telah dijabarkan di atas, perumusan hipotesis dalam penelitian ini adalah sebagai berikut: Utang berbasis bunga dan pendapatan non-halal berpengaruh negatif signifikan terhadap nilai perusahaan.

\section{METODE PENELITIAN}

\section{Pendekatan Penelitian}

Pendekatan yang digunakan dalam penelitian ini adalah pendekatan kuantitatif untuk menjawab rumusan masalah yakni mengkur hubungan pengaruh antara utang berbasis bunga dan pendapatan non-halal terhadap nilai perusahaan. Adapun variabel bebas dalam penelitian ini adalah utang berbasis bunga dan pendapatan non-halal. Sedangkan variabel terikat dalam penelitian ini adalah nilai perusahaan.

\section{Utang Berbasis Bunga}

Utang berbasis bunga merupakan pendanaan yang dilakukan oleh perusahaan yang didapatkan dari pihak eksternal dengan kontrak utang yang memiliki persyaratan imbal hasil/biaya modal berupa bunga. 
Dalam penelitian ini, nilai utang berbasis bunga akan diubah kedalam bentuk rasio dengan membagi utang berbasis bunga dengan total utang. Perhitungan rasio utang berbasis bunga (UBB) dilakukan untuk menyamakan satuan data yang diobservasi. Rumus menghitung rasio utang berbasis bunga dituliskan dalam persamaan 1.

$$
U B B=\frac{\text { Utang berbasis bunga }}{\text { Total Utang }}
$$

\section{Pendapatan Non-halal}

Pendapatan non-halal merupakan salah satu komponen pendapatan yang diperoleh perusahaan melalui kegiatan yang dilarang dalam syariat. Salah satu komponen pendapatan non-halal adalah pendapatan bunga yang diperoleh sebagai imbal hasil atas investasi berbasis bunga. Selain pendapatan bunga, pendapatan nonhalal juga bersumber dari usaha sampingan perusahaan yang tidak sesuai dengan prinsip syariat. Namun, karena kebanyakan perusahaan yang terdaftar sebagai emiten saham syariah bukan merupakan perusahaan yang berbasis syariah, umumnya hanya pendapatan bunga saja yang dipisahkan dari pendapatan usaha utama. Oleh karena itu, dalam penelitian ini, pendapatan non-halal akan diproksikan oleh pendapatan bunga.

Variabel pendapatan non-halal juga akan diubah kedalam bentuk rasio dengan membagi pendapatan non-halal dengan pendapatan usaha untuk menyamakan satuan data yang diobservasi. Rumus menghitung rasio pendapatan non-halal (PNH) dituliskan dalam persamaan 2.

$$
P N H=\frac{\text { Pendaptan nonhalal }}{\text { Pendapatan Usaha }}
$$

\section{Nilai Perusahaan}

Nilai perusahaan merupakan nilai yang sedia dibayarkan oleh investor ketika perusahaan dijual yang dicerminkan oleh harga saham. Penelitian ini menggunakan price to book value (PBV) untuk menghitung nilai perusahaan. PBV dihitung dengan membagi harga perlembar saham dengan nilai buku ekuitas perlembar saham (persamaan 3) atau dengan membagi total kapitalisasi pasar dengan total nilai buku ekuitas (persamaan 4).

$$
\begin{aligned}
P B V & =\frac{\text { Total } \text { kapitalisasi pasar }}{\text { Total nilai buku e } \text { kuitas }} \ldots . . . . .(3) \\
P B V & =\frac{\text { Harga per lembar saham }}{\text { Nilai buku ekuitas per lembar saham }}
\end{aligned}
$$




\section{Jenis dan Sumber Data}

Jenis data yang digunakan dalam penelitian ini adalah data sekunder yang berbentuk data panel karena observasi dilakukan pada beberapa perusahaan selama rentang waktu 2013-2017. Rentang waktu 2013-2017 diambil karena menyediakan data terbaru selama lima tahun kebelakang.

Nilai utang berbasis bunga, pendapatan bunga, total utang, pendapatan usaha, nilai buku ekuitas dan jumlah saham beredar didapatkan dari laporan keuangan tahunan perusahaan terkait. Sedangkan data harga saham diperoleh dari situs PT. Indo Premier Sekuritas (https://indopremier.com).

\section{Populasi dan Sampel}

Populasi penelitian ini adalah perusahaan-perusahaan yang terdaftar sebagai emiten saham syariah. Adapun teknik pengambilan sampel dalam penelitian ini menggunakan metode purposive sampling dengan kriteria sebagai berikut:

1. Perusahaan adalah emiten saham yang terdaftar dalam Jakarta Islamic Index (JII). Emiten-emiten yang terdaftar dalam JII dinilai dapat mewakili emiten-emiten syariah di Indonesia.

2. Sampel harus konsisten terdaftar sebagai konstituen JII selama periode 20132017.

Berdasarkan kriteria tersebut, diperoleh 15 perusahaan sebagai sampel penelitian. Dengan 15 emiten yang diobservasi selama lima periode, akan ada 75 total observasi dalam penelitian ini. Adapun daftar perusahaan tersebut terangkum dalam tabel 2.

Tabel 2

Sampel Penelitian

\begin{tabular}{rll}
\hline No & Kode & \multicolumn{1}{c}{ Nama Perusahaan } \\
\hline 1 & ADRO & PT. Adaro Energy Tbk. \\
\hline 2 & AKRA & PT. AKR Corporindo Tbk. \\
\hline 3 & ASII & PT. Astra International Tbk. \\
\hline 4 & BSDE & PT. Bumi Serpong Damai Tbk. \\
\hline 5 & ICBP & PT. Indofood CBP Sukses Makmur Tbk. \\
\hline 6 & INDF & PT. Indofood Sukses Makmur Tbk. \\
\hline 7 & KLBF & PT. Kalbe Farma Tbk. \\
\hline 8 & LPKR & PT. Lippo Karawaci Tbk. \\
\hline & & PT. Perusahaan Perkebunan London \\
9 & LSIP & Sumatra Indonesia Tbk. \\
\hline 10 & PGAS & PT. Perusahaan Gas Negara (Persero) Tbk. \\
\hline & &
\end{tabular}


Analisis Pengaruh Utang Berbasis Bunga Dan Pendapatan Non-Halal ...

\begin{tabular}{lll}
\hline No & Kode & Nama Perusahaan \\
\hline 11 & SMGR & PT. Semen Indonesia (Persero) Tbk. \\
\hline 12 & TLKM & PT. Telekomunikasi Indonesia (Persero) Tbk. \\
\hline 13 & UNTR & PT. United Tractors Tbk. \\
\hline 14 & UNVR & PT. Unilever Indonesia Tbk. \\
\hline 15 & WIKA & PT. Wijaya Karya (Persero) Tbk. \\
\hline
\end{tabular}

Sumber: http://www.syariahsaham.com

\section{Teknik Analisis}

Penelitian ini menggunakan teknik analisis regresi data panel untuk mengukur pengaruh utang berbasis non-halal dan pendapatan bunga terhadap nilai perusahaan. Proses analisis regresi data panel dilakukan menggunakan aplikasi STATA 14. Model regresi data panel menggabungkan aspek cross section dan time series dalam model. Model tersebut dituliskan dalam model persamaan 5 (Ghozali \& Ratmono, 2013:235).

$Y_{i t}=\alpha+\beta_{1} X_{1 i t}+\beta_{2} X_{2 i t}+\varepsilon$

Keterangan:

$\mathrm{Y}_{\mathrm{it}} \quad=$ Nilai variabel terikat (nilai perusahaan)

$\alpha \quad=$ Konstanta

$\beta_{1}, \beta_{2}=$ Koefisien regresi

$\mathrm{X}_{1}=$ Nilai variabel bebas 1 (UBB)

$\mathrm{X}_{2}=$ Nilai variabel bebas $2(\mathrm{PNH})$

$\mathrm{i} \quad=$ Observasi cross section

$\mathrm{t} \quad=$ Observasi time series

$\varepsilon \quad=$ error term

Regresi data panel umumnya memiliki tiga alternatif model yang dapat digunakan, yakni Common Effect Models (CEM) atau disebut juga Pooled OLS Models (POLS), Fixed Effect Models (FEM), dan Random Effect Models (REM).

Untuk menentukan model mana yang terbaik antara model CEM, FEM, atau REM, perlu dilakukan beberapa teknik analisis lebih lanjut.

a. Chow Test untuk memilih antara CEM atau FEM sebagai estimasi model yang lebih baik. Jika nilai probabilitas uji < 0,05 (signifikan) maka yang dipilih adalah model FEM (Ghozali, Ratmono, 2013:269).

b. Hausman Test untuk memilih antara FEM dan REM sebagai estimasi model yang lebih baik. Jika nilai probabilitas uji $<0,05$ (signifikan) maka yang dipilih adalah model FEM (Ghozali, Ratmono, 2013:291). 


\section{Uji Asumsi Klasik}

Setelah memilih model uji regresi data panel yang terbaik, selanjutnya perlu dilakukan uji asumsi klasik. Uji asumsi klasik meliputi uji normalitas, linearitas, multikolinearitas, uji heteroskedastisitas, dan uji autokorelasi.

Uji normalitas dilakukan dengan uji Shapiro-Wilk. Data dikatakan terdistribusi normal jika nilai signifikansi uji lebih dari 0,05 (Sugiyono \& Susanto, 2015:323). Namun pada data dengan jumlah observasi besar, lebih dari 10 observasi pervariabel, asumsi normalitas dapat diabaikan (Schmidt \& Finan, 2018).

Uji linearitas dilakukan dengan memeriksa scatterplot antara variabel bebas dan variabel terikat (Sugiyono \& Susanto, 2015:323-324). Dalam analisis data panel, tidak dapat diasumsikan bahwa semua individu dalam sampel memiliki karakteristik yang sama antara satu dengan yang lainnya. Oleh karena itu, pengujian linearitas dilakukan dengan melihat hubungan antarvariabel pada masing-masing perusahaan.

Uji multikolinearitas dilakukan dengan mengukur tingkat korelasi antarvariabel bebas. Jika tidak ada nilai korelasi antarvariabel bebas yang lebih dari 0,80 maka dapat dinyatakan bahwa tidak ada multikoleniaritas (Sugiyono \& Susanto, 2015:332).

Untuk uji heteroskedastisitasm jika nilai signifikansi uji heteroskedastisitas > 0,05 maka dapat disimpulkan tidak adanya heteroskedastisitas (Sugiyono \& Susanto, 2015:346).

Uji autokorelasi dilakukan dengan uji Durbin-Watson Adapun kriteria pengambilan keputusan uji Durbin-Watson ditunjukkan dalam tabel 3.

Tabel 3

Kriteria Pengambilan Keputusan Uji Durbin-Watson

\begin{tabular}{ll}
\hline \multicolumn{1}{c}{ Kondisi } & \multicolumn{1}{c}{ Keputusan } \\
\hline $0<D W<D_{L}$ & Ada autokorelasi positif \\
\hline$D_{L} \leq D W \leq D_{U}$ & Tidak ada keputusan \\
\hline $4-D_{L}<D W<4$ & Ada autokorelasi negatif \\
\hline $4-D_{U} \leq D W \leq 4-$ & Tidak ada keputusan \\
$D_{L}$ & \\
\hline$D_{U}<D W<4-D_{U}$ & $\begin{array}{l}\text { Tidak ada autokorelasi } \\
\text { positif dan negatif }\end{array}$ \\
\hline
\end{tabular}

Sumber: Ghozali \& Ratmono (2013:138)

\section{Uji Hipotesis}

Uji t mengukur pengaruh masing-masing variabel bebas terhadap variabel terikat secara parsial. Jika nilai signifikansi uji $\mathrm{t}>0,05$ maka $\mathrm{H}_{0}$ diterima atau hipotesis penelitian ditolak. Sebaliknya, jika nilai signifikansi uji $\mathrm{t}<0,05$ maka $\mathrm{H}_{0}$ ditolak dan menerima hipotesis penelitian (Windarjono, 2015:284).

Uji F mengukur pengaruh semua variabel bebas terhadap variabel terikat secara bersamaan. Jika nilai signifikansi uji $\mathrm{F}>0,05$ maka $\mathrm{H}_{0}$ diterima atau hipotesis penelitian ditolak. Sebaliknya, jika nilai signifikansi uji $\mathrm{F}<0,05$ maka $\mathrm{H}_{0}$ ditolak dan menerima hipotesis penelitian (Windarjono, 2015:281). 


\section{HASIL DAN PEMBAHASAN}

Penelitian ini mengobservasi ketiga variabel penelitian, yakni utang berbasis bunga (UBB); pendapatan non-halal (PNH); dan nilai perusahaan (PBV), dari 15 sampel penelitian yang diteliti selama lima periode (2013-2017). Dengan demikian, terdapat total 75 observasi pada masing-masing variabel. Tabel 4 menyediakan statistik deskriptif dari hasil observasi yang telah dilakukan.

Tabel 4 memuat nilai statistik deskripstif dengan estimator overall, between, dan within. Dari tabel 4 di atas, dapat diketahui bahwa nilai UBB memiliki nilai ratarata 0,4921 dengan nilai standar deviasi overall sebesar 0,1857 , serta nilai standar deviasi between sebesar 0,1806 yang lebih besar dari nilai standar deviasi within sebesar 0,0604 . Nilai terendah variabel UBB sebesar 0,1274 yang dimiliki PT. United Tractors Tbk. (UNTR) pada tahun 2016. Sedangkan nilai tertinggi variabel UBB adalah 0,8240 yang dimiliki oleh PT. Perusahaan Gas Negara (Persero) Tbk. (PGAS).

Nilai PNH memiliki nilai rata-rata sebesar 0,0099 dan standar deviasi sebesar overall 0,0087, serta nilai standar deviasi between sebesar 0,0084 yang lebih besar dari nilai standar deviasi within sebesar 0,0029. Nilai terendah variabel PNH adalah 0,0001 yang dimiliki oleh PT. Unilever Indonesia Tbk pada tahun 2017. Sedangkan nilai tertinggi variabel PNH adalah 0,0494 yang dimiliki oleh PT. Bumi Serpong Damai Tbk. (BSDE) pada tahun 2014.

PBV memiliki nilai rata-rata 6,4649 dengan standar deviasi overall sebesar 14,9690, serta nilai standar deviasi between sebesar 15,0198 yang lebih besar dari nilai standar deviasi within sebesar 3,2666. Nilai terendah variabel PBV adalah 0,3552 yang dimiliki PT. Adaro Energy Tbk. pada tahun 2015. Sedangkan nilai PBV tertinggi dimiliki oleh PT. Unilever Indonesia Tbk. dengan nilai sebesar 82,4444.

Tabel 4

Statistik Deskriptif

\begin{tabular}{llrrrr}
\hline Variabel & \multicolumn{1}{c}{ Estimator } & Mean & Std. Dev. & Min & Max \\
\hline PBV & Overall & 6,4649 & 14,9690 & 0,3552 & 82,4444 \\
\cline { 2 - 6 } & Between & - & 15,0198 & 0,8423 & 60,4810 \\
\cline { 2 - 6 } & Within & - & 3,2666 & $-7,3897$ & 28,4282 \\
& & & & & \\
\hline UBB & Overall & 0,4921 & 0,1857 & 0,1274 & 0,8240 \\
\cline { 2 - 6 } & Between & - & 0,1806 & 0,1867 & 0,7692 \\
\cline { 2 - 6 } & Within & - & 0,0604 & 0,3139 & 0,6962 \\
\hline PNH & Overall & 0,0099 & 0,0087 & 0,0001 & 0,4940 \\
\cline { 2 - 6 } & Between & - & 0,0084 & 0,0003 & 0,3708 \\
\cline { 2 - 6 } & Within & - & 0,0029 & $-0,0015$ & 0,2219
\end{tabular}

Sumber: Hasil analisis STATA 14, diolah 
Dari hasil analisis statistik deskriptif di atas, dapat diketahui bahwa semua variabel memiliki standar deviasi between yang lebih besar dibandingkan standar deviasi within. Hal ini menunjukkan bahwa semua variabel memiliki variasi yang lebih tinggi jika dibandingkan antara satu perusahaan dengan perusahaan yang lain daripada jika dibandingkan dari waktu ke waktu dalam satu perusahaan. Hal ini berarti masing-masing perusahaan memiliki karakteristik yang berbeda-beda satu dengan yang lainnya. Sedangkan karakteristik satu perusahaan cenderung tidak berubah dari waktu ke waktu.

\section{Analisis Model Regresi Data Panel}

Sebelum melakukan pemilihan model mana yang paling tepat untuk digunakan dalam penelitian ini, terlebih dulu dilakukan estimasi awal menggunakan semua model yang dapat dipergunakan yang tersaji dalam tabel 5 .

Setelah mendapatkan hasil estimasi dengan tiga jenis model yang tersedia, selanjutnya adalah memilih model mana yang paling baik untuk digunakan dalam penelitian ini. Pemilihan estimasi model dilakukan dengan uji Chow dan uji Hausman. Adapun ringkasan hasil uji Chow dan uji Hausman tersaji dalam tabel 6 dan tabel 7. Secara keseluruhan, hasil pada tabel 6 dan tabel 7 menunjukkan bahwa FEM adalah model estimasi regresi data panel yang paling tepat digunakan dalam penelitian ini.

Tabel 5

Ringkasan Hasil Estimasi dengan CEM, FEM, dan REM

\begin{tabular}{|c|c|c|c|c|}
\hline & \multirow[t]{2}{*}{ Variabel } & \multicolumn{3}{|c|}{ Model Estimasi } \\
\hline & & CEM & FEM & REM \\
\hline \multirow[t]{5}{*}{ Constant } & Coefficient & 24,549 & 0,199 & 3,581 \\
\hline & Std. Err. & 4,566 & 3,934 & 5,280 \\
\hline & $t \quad$ statistics $/ z$ & 5,380 & 0,050 & 0,680 \\
\hline & statistics & & & \\
\hline & Probability & 0,000 & 0,960 & 0,498 \\
\hline \multirow[t]{5}{*}{ UBB } & Coefficient & $-28,333$ & 11,537 & 6,208 \\
\hline & Std. Err. & 8,555 & 7,010 & 6,797 \\
\hline & statistics/z & $-3,310$ & 1,650 & 0,910 \\
\hline & statistics & & & \\
\hline & Probability & 0,001 & 0,105 & 0,361 \\
\hline \multirow[t]{4}{*}{$\mathrm{PNH}$} & Coefficient & $-419,208$ & 59,462 & $-17,371$ \\
\hline & Std. Err. & 182,610 & 143,259 & 139,548 \\
\hline & $t \quad$ statistics $/ z$ & $-2,300$ & 0,420 & $-0,120$ \\
\hline & statistics & & & \\
\hline
\end{tabular}


Analisis Pengaruh Utang Berbasis Bunga Dan Pendapatan Non-Halal ...

\begin{tabular}{|c|c|c|c|}
\hline Variabel & CEM & FEM & REM \\
\hline Probability & 0,025 & 0,680 & 0,901 \\
\hline F statistics/Wald Chi sq. & 9,670 & 1,370 & 0,890 \\
\hline Probability & 0,000 & 0,262 & 0,642 \\
\hline$R$ squared & 0,212 & - & - \\
\hline Adjusted $R$ squared & 0,190 & - & - \\
\hline$R$ squared Overall & - & 0,190 & 0,128 \\
\hline$R$ squared Between & - & 0,235 & 0,164 \\
\hline$R$ squared Within & - & 0,045 & 0,039 \\
\hline
\end{tabular}

Sumber: Hasil analisis STATA 14, diolah.

Tabel 6

Ringkasan Uji Chow

\begin{tabular}{crl}
\hline F hitung & Probabilitas & \multicolumn{2}{c}{ Keputusan } \\
\hline 67,67 & 0,0000 & Model FEM lebih \\
& & tepat
\end{tabular}

Sumber: Hasil analisis STATA 14, diolah

Tabel 7

Ringkasan Uji Hausman

\begin{tabular}{ccl}
\hline $\begin{array}{c}\text { Chi squared } \\
\text { hitung }\end{array}$ & Probabilitas & Keputusan \\
\hline 9,66 & 0,0080 & $\begin{array}{l}\text { Model FEM } \\
\text { lebih tepat }\end{array}$
\end{tabular}

Sumber: Hasil analisis STATA 14, diolah

\section{Uji Asumsi Klasik}

Asumsi normalitas dalam model penelitian ini dapat diabaikan karena memiliki jumlah observasi yang banyak, yakni 75 observasi Schmidt \& Finan (2018).

Uji linearitas dalam penelitian ini menggunakan hubungan antara variabel bebas dan variabel terikat yang digambarkan dalam scatterplot. Gambar 2 sampai gambar 16 menunjukkan hubungan variabel UBB dengan PBV pada tiap perusahaan. Sedangkan gambar 17 sampai 31 menunjukkan hubungan antara variabel PNH dengan PBV pada tiap perusahaan. Scatterplot dan garis regresi digambar dengan menggunakan aplikasi EViews 10 untuk mendapatkan hasil yang lebih baik. 
Adlan dan Mawardi | Jurnal Ekonomi dan Bisnis Islam, Vol. 4, No. 2, Juni-Des 2018

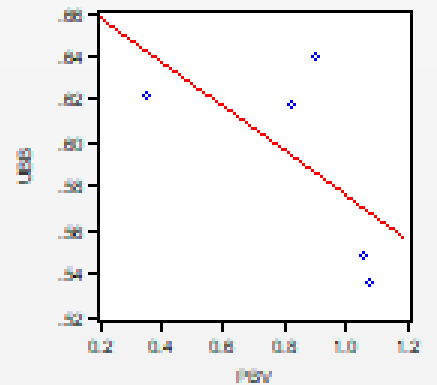

Gambar 2

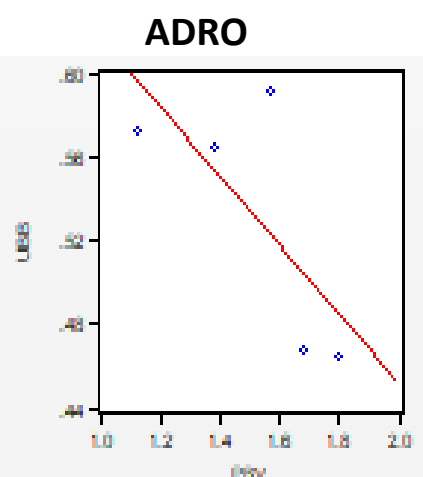

Gambar 5

BSDE

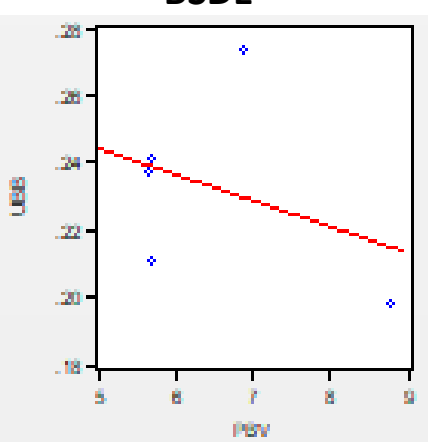

Gambar 8

KLBF

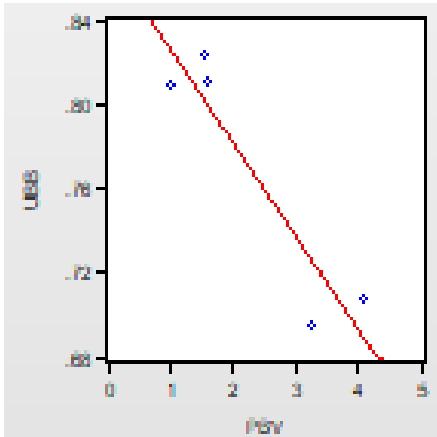

Gambar 11

PGAS

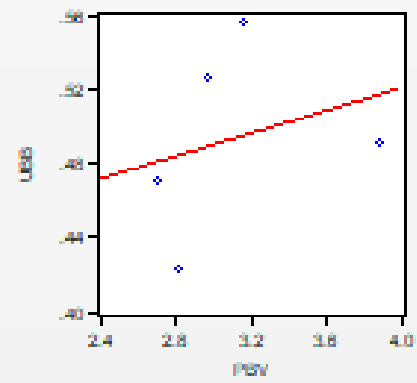

Gambar 3

AKRA

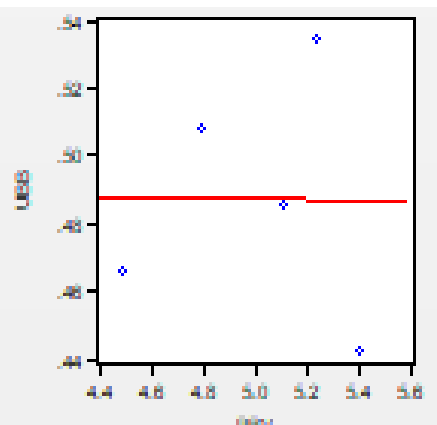

Gambar 6

ICBP

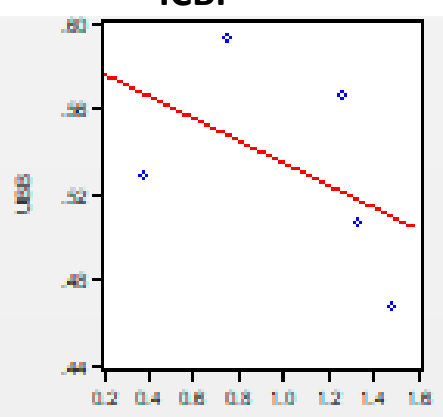

Gambar 9

LPKR

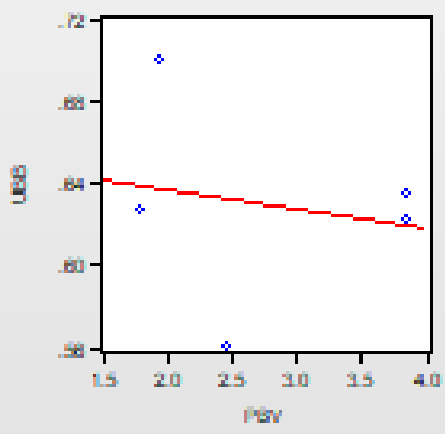

Gambar 12

SMGR

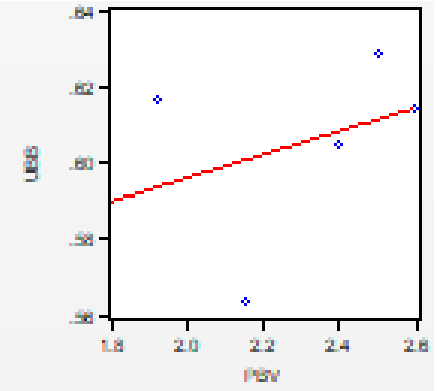

Gambar 4 ASII

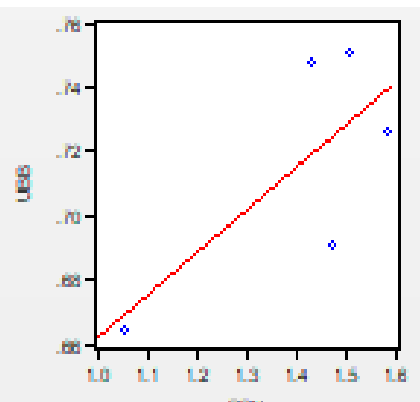

Gambar 7

INDF

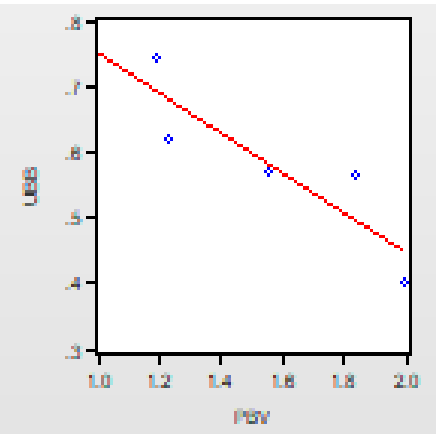

Gambar 10

LSIP

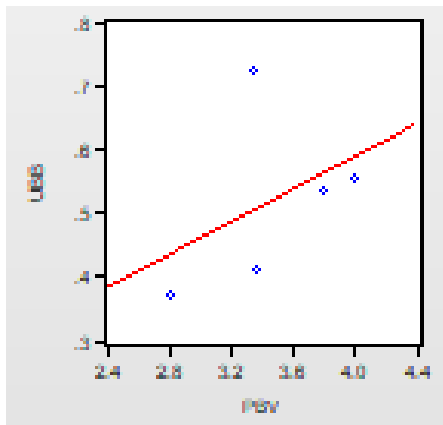

Gambar 13

TLKM 
Analisis Pengaruh Utang Berbasis Bunga Dan Pendapatan Non-Halal ...

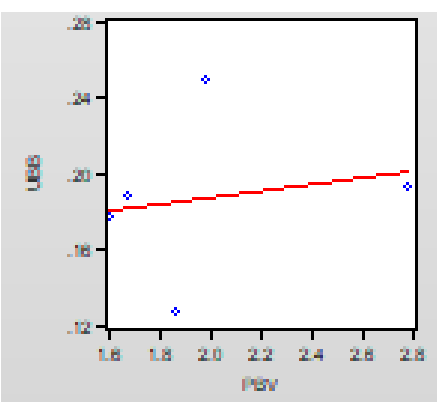

Gambar 14

UNTR

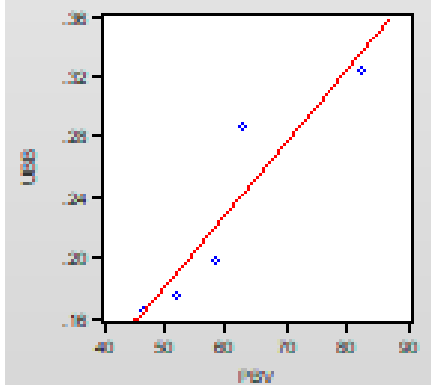

Gambar 15

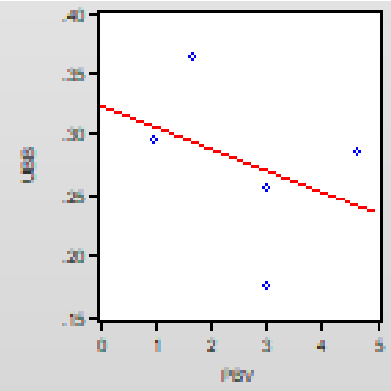

Gambar 16

WIKA

Sumber: Hasil analisis EViews 10

Gambar 2 sampai gambar 16.

Hubungan Variabel UBB dan PBV pada Masing-masing Perusahaan

ADRO

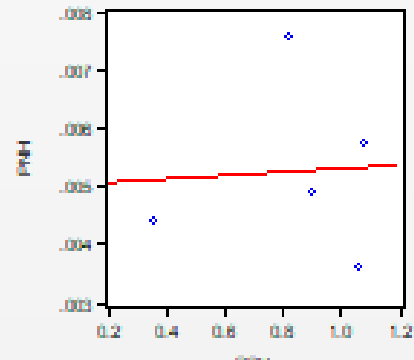

Gambar 17

ADRO

BSDE

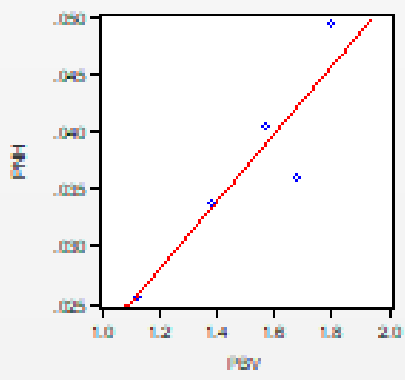

Gambar 20

BSDE

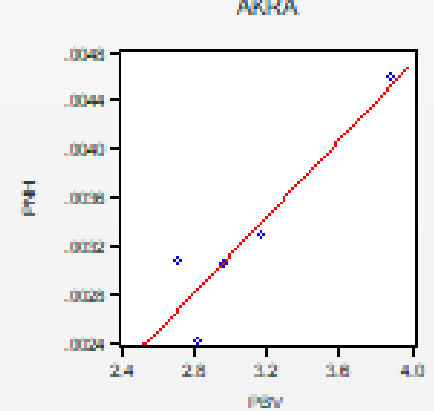

Gambar 18

AKRA

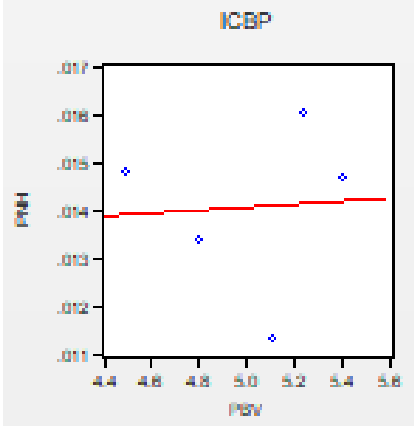

Gambar 21

ICBP

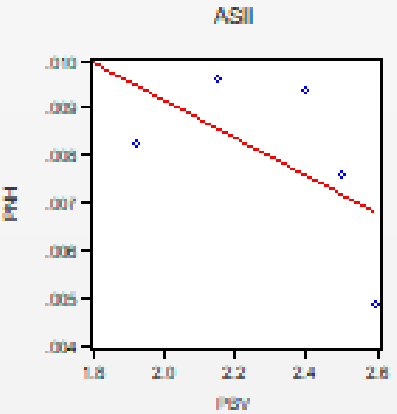

Gambar 19

ASII

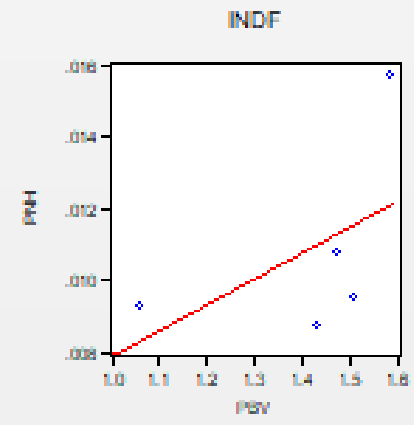

Gambar 22

INDF

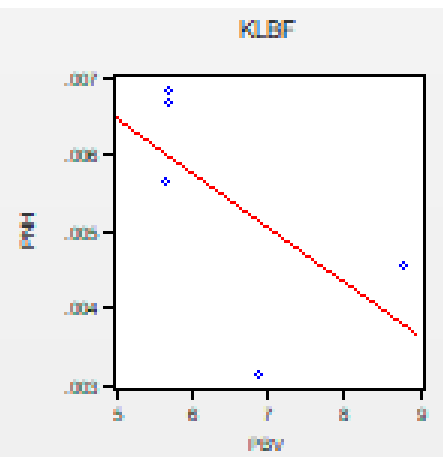

Gambar 23

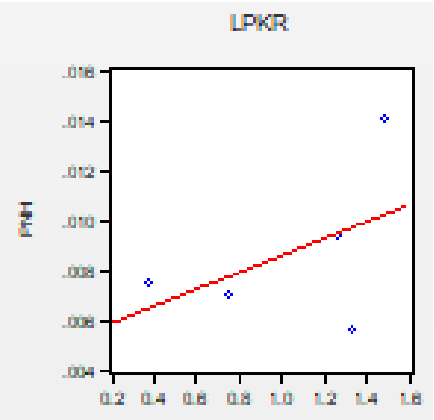

Gambar 24

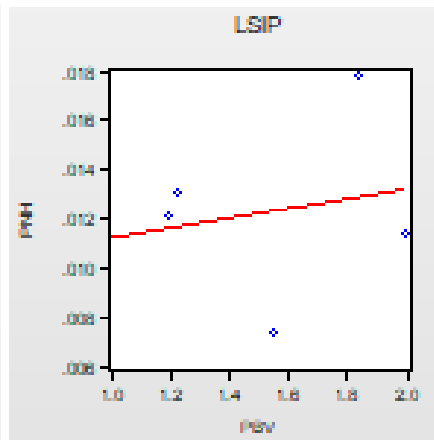

Gambar 4.2254 


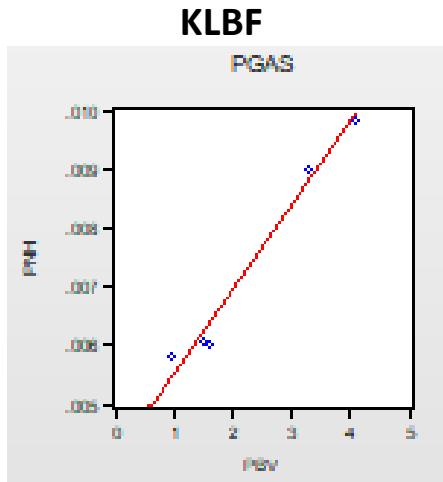

Gambar 26

PGAS

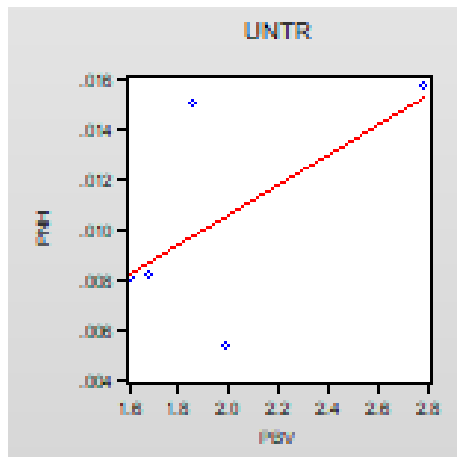

Gambar 29

UNTR

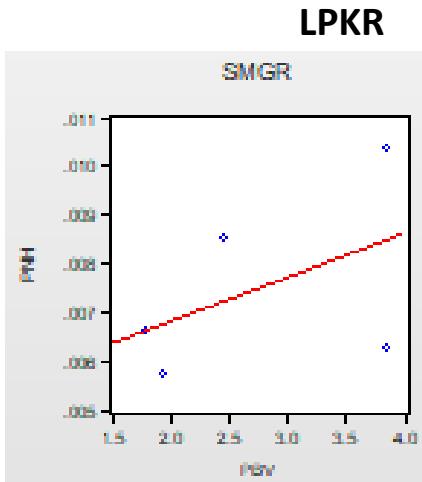

Gambar 27

SMGR

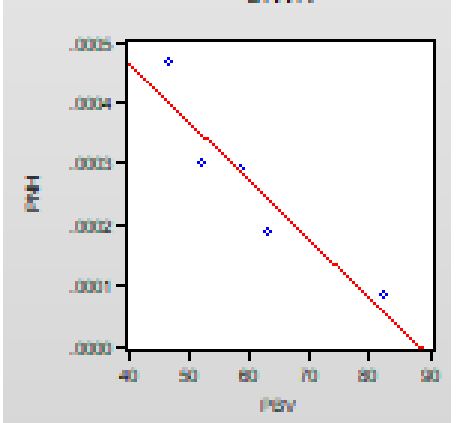

Gambar 30

UNVR

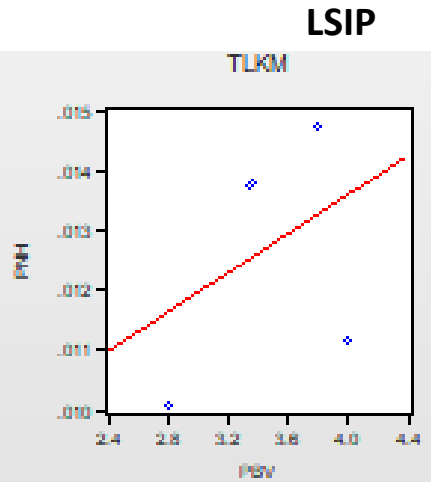

Gambar 28

TLKM

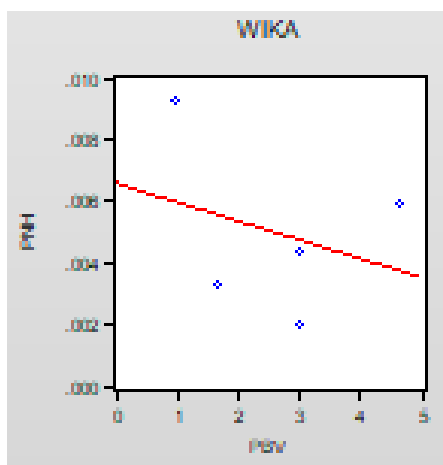

Gambar 31

WIKA

Sumber: Hasil analisis EViews 10

Gambar 17 sampai 31.

Hubungan Variabel PNH dan PBV pada Masing-masing Perusahaan

Tabel 8

Uji Multikolinearitas

\begin{tabular}{llll}
\hline Variabel & UBB & PNH & Keputusan \\
\hline UBB & 1,0000 & & Tidak terdapat \\
& & & Multikolinearitas \\
\hline PNH & 0,1682 & 1.0000 &
\end{tabular}

Sumber: Hasil analisis STATA 14, diolah

Tabel 9

Uji Heteroskedastisitas

Chi-squared Probabilitas Keputusan

Hitung

$\begin{array}{lll}5,3 e+05 & 0,0000 & \text { Terdapat } \\ & \text { heteroskedastisitas }\end{array}$

Sumber: Hasil analisis STATA 14 
Analisis Pengaruh Utang Berbasis Bunga Dan Pendapatan Non-Halal ...

Tabel 10

Uji Autokorelasi

\begin{tabular}{ccccl}
\hline $\begin{array}{c}\text { DW } \\
\text { Hitung }\end{array}$ & $\mathbf{D}_{\mathrm{L}}$ & $\mathrm{D}_{\mathrm{U}}$ & 4- $_{\mathrm{U}}$ & Keputusan \\
\hline 0,872445 & 1,5709 & 1.6802 & 2,3198 & Terdapat \\
& & & & autokorelasi
\end{tabular}

Sumber: Hasil analisis EViews 10; Tabel Durbin-Watson pada alpha 5\%, diolah

Gambar 2 sampai gambar 16 menunjukkan adanya hubungan linear antara variabel UBB dengan variabel PBV untuk masing-masing perusahaan. Hal tersebut dapat diamati dari sebaran titik-titik scatterplot dan garis regresi yang dihasilkan. Sedangkan gambar 17 sampai gambar 31 menunjukkan pula adanya hubungan linear antara variabel PNH dengan variabel PBV untuk masing-masing perusahaan. Dengan demikian dapat diputuskan bahwa asumsi linearitas terpenuhi.

Tabel 8 menunjukkan hasil uji multikolinearitas. Tabel 9 menunjukkan ringkasan hasil uji heteroskedastisitas untuk estimasi FEM. Sedagkan tabel 10 menunjukkan ringkasan hasil uji autokorelasi untuk estimasi FEM yang didapatkan dari aplikasi EViews 10 menggunakan uji Durbin-Watson. Aplikasi STATA 14 tidak mendukung uji DW.

Fixed Effects Model dengan Robust Standard Errors

Uji Chow dan uji Hausman yang telah dilakukan sebelumnya menunjukkan bahwa FEM merupakan estimasi yang paling tepat untuk digunakan dalam penelitian ini. Namun terdapat masalah heteroskedastisitas dan autokorelasi dalam model. Untuk mengatasi masalah tersebut, dapat dilakukan perbaikan pada model menggunakan robust standard errors (Hoechle, 2007). Tabel 11 menunjukkan ringkasan hasil estimasi regresi data panel menggunakan Fixed Effects Model dan robust standard errors.

Dari hasil estimasi regresi data panel yang disajikan dalam tabel 11, didapatkan model regresi data panel yang dituliskan dalam persamaan 6 berikut:

$P B V=0,119+11,537(U B B)+59,4616(P N H)+\varepsilon \ldots .(6)$ 
Adlan dan Mawardi | Jurnal Ekonomi dan Bisnis Islam, Vol. 4, No. 2, Juni-Des 2018

Tabel 11

Hasil Estimasi Regresi Data Panel dengan FEM dan Robust Standard Errors

Variabel Koefisien Robust Std. thitung Probabilitas t

Err.

\begin{tabular}{lrrrr}
\hline Konstanta & 0,1995 & 7,4779 & 0,03 & 0,979 \\
\hline UBB & 11,5370 & 14,4996 & 0,80 & 0,440 \\
\hline PNH & 59,4616 & 49,0996 & 1,21 & 0,246
\end{tabular}

\begin{tabular}{lll}
\hline F hitung & 0,7300 \\
\hline Probabilitas $\mathrm{F}$ & 0,4973 \\
\hline \multirow{3}{*}{$R$ squared } & Overall & 0,1903 \\
\cline { 2 - 3 } & Between & 0,2345 \\
\cline { 2 - 3 } & Within & 0,0451 \\
\hline Rho $(\rho)$ & 0,9529
\end{tabular}

Sumber: Hasil analisis STATA 14, diolah

\section{Uji Hipotesis}

Hasil uji hipotesis dapat dilihat pada tabel 11 yang menyajikan hasil estimasi FEM dengan Robust Standard Errors. Nilai probabilitas t untuk variabel UBB adalah 0,440 (lebih dari 0,05). Sedangkan nilai probabilitas t untuk variabel PNH adalah 0,246 (lebih dari 0,05). Maka dapat disimpulkan bahwa baik utang berbasis bunga maupun pendapatan non-halal tidak berpengaruh secara persial terhadap nilai perusahaan.

Adapun nilai probabilitas $F$ adalah 0,4973 (lebih dari 0,05). Maka dapat disimpulkan bahwa utang berbasis bunga dan pendapatan non-halal tidak berpengaruh terhadap nilai perusahaan.

\section{Pembahasan}

Dari hasil analisis model regresi data panel dengan Fixed Effects Model dan Robust Standard Errors di atas, dapat disimpulkan bahwa utang berbasis bunga dan pendapatan non-halal tidak berpengaruh terhadap nilai perusahaan, baik secara parsial maupun secara simultan. Hal tersebut membuktikan bahwa keputusan perusahaan dalam mengelola utang berbasis bunga dan pendapatan non-halal tidak diperhatikan oleh investor dalam mengambil keputusan investasi pada emitenemiten syariah.

Dalam hasil penelitian Yazi et. Al. (2015) yang membandingkan harga saham dari perusahaan-perusahaan yang bertahan dalam daftar Sharia-compliant Stock (SCS) dengan perusahaan-perusahaan yang keluar dari daftar SCS, memang terjadi kenaikan harga saham pada perusahaan-perusahaan yang bertahan dalam daftar SCS setelah mengalami pengetatan regulasi. Sebaliknya, perusahaan yang keluar dari 
daftar SCS mengalami penurunan harga saham. Namun hasil tersebut tidak secara langsung berimplikasi bahwa investor memperhatikan aspek pembatasan instrumen keuangan berbasis riba. Investor hanya memperhatikan aspek syariah perusahaan berupa ada tidaknya perusahaan dalam daftar saham syariah. Jika terdapat perusabahan regulasi yang mengeluarkan beberapa emiten dari daftar syariah, maka investor muslim yang religius akan mengikuti peraturan tersebut dan memilih sahamsaham yang bertahan di dalam daftar sehingga ada perbedaan nilai perusahaan antara saham yang terdaftar sebagai saham syariah dengan saham yang tidak terdaftar sebagai saham syariah. Investor cenderung tidak melakukan analisis mendalam tentang pembatasan instrumen keuangan berbasis riba dan memilih mengikuti peraturan resmi yang dirilis oleh otoritas terkait dalam hal penerbitan saham syariah.

Alahqatani \& Boulanouar (2017) juga mencatatkan bahwa saham yang patuh syariah lebih disukai investor dalam proses IPO. Meskipun hasil tersebut menyatakan saham syariah lebih diminati oleh investor muslim yang religius, namun tidak dijelaskan apakah investor juga memperhatikan besarnya instrumen keuangan berbasis riba yang dimiliki oleh perusahaan. Investor muslim yang religius mungkin menyukai saham syariah sebatas pada apakah saham suatu perusahaan tergolong saham syariah atau tidak.

Hasil penelitian Agustin \& Mawardi (2014) menyatakan investor muslim yang memperhatikan faktor agama hanya akan berinvestasi pada saham syariah, namun investor muslim juga menerapkan perilaku rasional dan adanya faktor psikologis dalam mengambil keputusan investasi. Perilaku rasional yang mempengaruhi keputusan investasi investor muslim antara lain neutral information (informasi dari pihak luar dan kondisi ekonomi), accounting information (informasi akuntansi, terutama yang berhubungan dengan profitabilitas), dan social relevance (posisi suatu saham di pasar modal). Adapun faktor psikologis yang memengaruhi keputusan investor muslim antara lain status quo (cenderung bertahan pada suatu saham), anchoring (keputusan jual-beli yang dipengaruhi pergerakan harga), dan lost aversion (rasa sedih karena penurunan nilai investasi).

Sebelum berinvestasi pada saham suatu perusahaan, investor tentu terlebih dahulu akan memeriksa beberapa hal terkait perusahaan tersebut. Hal-hal yang diperhatikan investor mulai dari kondisi perekonomian secara luas, kondisi industri yang dijalani oleh perusahaan, kinerja perusahaan itu sendiri, hingga pergerakan harga pasar saham perusahaan tersebut (Jones, et.al, 2009). Analisis fundamental dan teknikal lebih diperhatikan oleh investor dalam mengambil keputusan investasi (Maditinos, et. al., 2006). Perilaku rasional dan faktor psikologis tampak memberikan pengaruh yang cukup besar bagi keputusan investasi investor muslim dibandingkan faktor religiositas.

Selain itu, fakta bahwa tidak semua investor muslim memperhatikan faktor religius membuat tidak semua investor muslim melakukan perilaku investasi yang 
ketat hanya pada saham-saham syariah. Tahir \& Brimble (2011) menyatakan dalam hasil penelitian bahwa tingkat religiositas juga memengaruhi seberapa ketat seorang investor muslim berinvestasi pada saham-saham syariah. Seorang investor muslim, mungkin saja tidak berinvestasi pada saham syariah sama sekali, hanya menginvestasilan sebagaian porsi dana saja pada saham syariah, atau sepenuhnya berinvestasi pada saham syariah. Fakta tersebut mungkin juga membuat aspek kesyariahan perusahaan tidak terlalu berpengaruh pada preferensi investor dan nilai perusahaan tersebut.

Faktor lain yang menyebabkan aspek kesyariahan perusahaan tidak berpengaruh terhadap nilai perusahaan adalah sedikitnya jumlah pelaku sektor keuangan syariah di Indonesia yang benar-benar hanya berinvestasi pada saham syariah karena didasarkan pada faktor religiositas. Karim Business Consulting (2005) dalam Irviana dkk. (2008) menyebutkan bahwa segmen pasar perbankan syariah dapat dibedakan menjadi tiga bagian, yakni loyalis syariah, masa mengambang, dan loyalis konvensional. Silviana \& Putra (2017) lebih lanjut menyebutkan bahwa segmen masa mengambang memiliki jumlah yang paling besar di antara ketiga segmen tersebut. Segmen masa mengambang ini digambarkan sebagai segmen yang menjadi nasabah bank syariah tanpa meninggalkan bank konvensional. Segmen masa mengambang juga digambarkan sebagai segmen yang sangat memperhatikan aspek biaya dan keuntungan dalam memilih untuk menjadi nasabah bank konvensional atau bank syariah. Secara umum, data banyaknya nasabah perbankan yang termasuk kedalam segmen masa mengambang dapat diasosiasikan pada keseluruhan pelaku sektor keuangan syariah, termasuk pasar modal syariah.

\section{SIMPULAN}

Berdasarkan hasil penelitian tentang pengaruh utang berbasis bunga dan pendapatan non-halal terhadap nilai perusahaan yang terdaftar dalam Jakarta Islamic Index (JII) pada tahun 2013-2017, dapat ditarik kesimpulan bahwa utang berbasis bunga dan pendapatan non-halal tidak berpengaruh terhadap nilai perusahaan, baik secara parsian maupun secara simultan. Hal ini terjadi karena adanya indikasi bahwa pilihan-pilihan investasi investor lebih banyak dipengaruhi aspek rasionalitas dan/atau aspek psikologis dari pada aspek religiositas investor. Selain itu, tidak semua investor, dalam hal ini terutama investor muslim, adalah investor yang memperhatikan aspek kesyariahan secara ketat terhadap pemilihan investasi yang dilakukan.

Dilain pihak, seorang investor muslim yang memperhatikan aspek kepatuhan syariah dan ketat dalam melakukan pilihan investasi pada saham syariah, hanya memperhatikan apakah saham sebuah perusahaan terdaftar dalam daftar saham syariah atau tidak. Jika saham sebuah perusahaan dinyatakan terdaftar dalam daftar saham syariah, maka investor akan memilih berinvestasi di saham tersebut. Sebaliknya, jika saham suatu perusahaan tidak dinyatakan terdaftar dalam daftar 
saham syariah, maka investor cenderung menghindarinya. Hal tersebut sangat mungkin dapat memberikan perbedaan nilai perusahaan antara saham yang terdaftar sebagai saham syariah dengan perusahaan yang tidak terdaftar sebagai saham syariah.

\section{DAFTAR PUSTAKA}

Agustin, Pramita, dan Imron Mawardi. (2014). Perilaku Investor Muslim dalam Bertransaksi Saham di Pasar Modal. Jurnal Ekonomi Syariah Teori dan Terapan (Online), 1 (12), 874-892

Al Arif, M. Nur Rianto, dan Euis Amalia. 2010. Teori Mikroekonomi: Suatu Perbandingan Ekonomi Islam dan Ekonomi Konvensional. Jakarta: Kencana.

Alqahtani, F., \& Boulanouar, Z. (2017). Sharia compliance status \& investor demand for IPOs: Evidence from Saudi Arabia. Pacific-Basin Finance Journal, 46, 258268.

Al-Qur'an Kementerian Agama Republik Indonesia Online diakses melalui http://quran.kemenag.go.id

Az-Zuhaili, Wahbah. 2014. Tafsir al-Munir: Aqidah, Syari'ah, Manhaj, terj. Abdul Hayyie al-Kattani, dkk. Jilid 14. Jakarta: Gema Insani.

Badan Pengawas Pasar Modal dan Lembaga Keuangan. (2007). Salinan Keputusan Ketua Badan Pengawas Pasar Modal Dan Lembaga Keuangan Nomor: Kep314/BL/2007 Tentang Kriteria dan Penerbitan Daftar Efek Syariah.

Badan Pengawas Pasar Modal dan Lembaga Keuangan. (2012a). Salinan Keputusan Ketua Badan Pengawas Pasar Modal dan Lembaga Keuangan Nomor: Kep208/BL/2012 Tentang Kriteria dan Penerbitan Daftar Efek Syariah.

Berg, N., \& Kim, J. Y. (2014). Prohibition of Riba and Gharar: A signaling and screening explanation?. Journal of Economic Behavior \& Organization, 103, S146-S159.

Berk, Jonathan, et. al. (2013). Fundamentals of Corporate Finance, Second Edition. Harlow, Inggris: Pearson Education.

Cheng, M. C., \& Tzeng, Z. C. (2011). The effect of leverage on firm value and how the firm financial quality influence on this effect. World Journal of Management, 3(2), 30-53.

Dewan Syariah Nasional Majelis Ulama Indonesia. (2001). Fatwa DSN-MUI nomor 20/DSN- MUI/IV/2001 Tentang Pedoman Pelaksanaan Investasi Untuk Reksa Dana Syari'ah.

Dewan Syariah Nasional Majelis Ulama Indonesia. (2003a). Fatwa DSN-MUI nomor 40/DSN-MUI/X/2003 Tentang Pasar Modal dan Pedoman Umum Penerapan Prinsip Syariah di Bidang Pasar Modal. 
Djazuli, A. (2017). Kaidah-kaidah Fikih: Kaidah-kaidah Hukum Islam dalam Menyelesaikan Masalah-masalah yang Praktis. Jakarta: Kencana.

Fabozzi, Frank J., dan Franco Modigliani. (2003). Capital Markets: Institutions and Instruments, Third Edition. Upper Saddle River, Amerika Serikat: Prentice Hall.

Ghazaly, Abdul Rahman, dkk. (2012). Fiqh Muamalat. Jakarta: Kencana.

Ghozali, Imam \& Dwi Ratmono. (2013). Analisis Multivariat dan Ekonometrika: Teori, Konsep dan Aplikasi dengan Eviews 8. Semarang: Badan Penerbit Undip.

Gitman, Lawrence J. (2006). Principles of Managerial Finance, Eleventh Edition. Boston, Amerika Serikat: Pearson Addison Wesley.

Harahap, Sofyan Syafri. (2012). Teori Akuntansi, Edisi Revisi 2011. Jakarta: Rajawali Pers.

Hoechle, D. (2007). Robust standard errors for panel regressions with cross-sectional dependence. Stata Journal, 7(3), 281.

Hoetoro, Arif. (2017). Ekonomi Islam: Perspektif Historis dan Metodologis. Malang: Empatdua.

International Shari'ah Research Academy for Islamic Finance. (2011). Islamic Financial System: Principles \& Operations. Kuala Lumpur, Malaysia: International Shari'ah Research Academy for Islamic Finance.

Jones, Charles P., et.al. (2009). Investment: Analysis and Management (An Indonesian Adaptation). Jakarta: Salemba Empat.

Kuncoro, Mudrajat. (2013). Metode Riset untuk Bisnis \& Ekonomi: Bagaimana Meneliti dan Menulis Tesis?. Jakarta: Penerbit Erlangga.

Lo, E. W. (2012). Pengaruh Tingkat Kesulitan Keuangan Terhadap Manajemen Laba: Teori Keagenan Versus Teori Signaling. Jurnal Riset Akuntansi dan Keuangan, 8(1), 1-18.

Lys, T., Naughton, J. P., \& Wang, C. (2015). Signaling through corporate accountability reporting. Journal of Accounting and Economics, 60(1), 56-72.

Maditinos, D. I., Šević, Ž., \& Theriou, N. G. (2007). Investors' behaviour in the Athens Stock Exchange (ASE). Studies in economics and Finance, 24(1), 32-50.

Dewi, R. K., \& Widagdo, B. (2013). Pengaruh Corporate Social Responsibility Dan Good Corporate Governance Terhadap Kinerja Perusahaan. Jurnal Manajemen Bisnis, 2(1).

Mayo, Herbert B. (2017). Investments: An Introduction, Twelfth Edition. Boston, Amerika Serikat: Cengage Learning.

McEachern, William A. (2006). Microeconomics: A Contemporary Introduction, Seventh Edition. Mason, Amerika Serikat: Thomson South-Western.

Paminto, A., Setyadi, D., \& Sinaga, J. (2016). The Effect of Capital Structure, Firm Growth and Dividend Policy on Profitability and Firm Value of the Oil Palm 
Analisis Pengaruh Utang Berbasis Bunga Dan Pendapatan Non-Halal ...

Plantation Companies in Indonesia. European Journal of Business and Management, 8(33).

Abdul Rahman, A., Azlan Yahya, M., \& Herry Mohd Nasir, M. (2010). Islamic norms for stock screening: A comparison between the Kuala Lumpur stock exchange Islamic index and the dow jones Islamic market index. International Journal of Islamic and Middle Eastern Finance and Management, 3(3), 228-240.

Rochmah, S. A., \& Fitria, A. (2017). Pengaruh kinerja keuangan terhadap nilai perusahaan: kebijakan dividen sebagai variabel moderating. Jurnal IImu Dan Riset Akuntansi, 6(3).

Ross, S.A., dkk. 2015. Corporate Finance: Core Principles and Applications, Asia Global Edition. New York: Mc-Graw-Hill Education.

Sabrin, A., Sarita, B., Takdir, D., \& Sujono, C. (2016). The effect of profitability on firm value in manufacturing company at Indonesia Stock Exchange. The International Journal of Engineering and Science, 5(10), 81-89.

Schmidt, A. F., \& Finan, C. (2018). Linear regression and the normality assumption. Journal of clinical epidemiology, 98, 146-151.

Shihab, Muhammad Quraish. (2009). Tafsir Al-Misbah: Pesan, Kesan, dan Keserasian al-Qur'an Volume 14. Jakarta: Lentera Hati.

Sudana, I Made. (2011). Manajemen Keuangan Perusahaan: Teori \& Praktik. Jakarta: Penerbit Erlangga.

Sugiyono \& Agus Susanto. (2015). Cara Mudah Belajar SPSS dan LISREL: Teori dan Aplikasi untuk Analisis Data Penelitian. Bandung: Alfabeta.

Tahir, I., \& Brimble, M. (2011). Islamic investment behaviour. International Journal of Islamic and Middle Eastern Finance and Management, 4(2), 116-130.

Umar, Z. (2017). Islamic vs conventional equities in a strategic asset allocation framework. Pacific-Basin Finance Journal, 42, 1-10.

Verawaty, V., Merina, C. I., \& Kurniawati, I. (2016). Analisis Pengembangan Corporate Value berdasarkan Keputusan Investasi dan Pendanaan, Struktur Kepemilikan serta Kebijakan Dividen pada Perusahaan Manufaktur yang Terdaftar di Bursa Efek Indonesia. Berkala Akuntansi dan Keuangan Indonesia, 1(1).

Vriend, N. J. (1996). Rational behavior and economic theory. Journal of Economic Behavior \& Organization, 29(2), 263-285.

Yafiz, M. (2008). Saham dan pasar modal syariah: Konsep, sejarah dan Perkembangannya. Jurnal MIQOT, 32(2).

Yazi, E., Morni, F., \& Imm, S. S. (2015). The effects of Shariah compliance announcement towards stock price changes in Malaysia. Journal of Economics, Business and Management, 3(11), 1019-1023. 